\title{
Taguchi Optimisation In Machining EN18 Using Coated Tool Under Dry and MQL Condition
}

\author{
Kosaraju Satynarayana ${ }^{1, *}$, Are Swathi ${ }^{2}$, Kesari Neeraja ${ }^{2}$, Madipali Samaikhya ${ }^{2}$, and Kumkuma Rajkiran ${ }^{3}$ \\ ${ }^{1}$ Assoc.Professor, GRIET, Mechanical Engineering Department, Bachupally 500090, Hyderabad, India. \\ ${ }^{2}$ UG Student, GRIET, Mechanical Engineering Department, Bachupally 500090, Hyderabad, India. \\ ${ }^{3}$ PG Student, GRIET, Mechanical Engineering Department, Bachupally 500090, Hyderabad, India.
}

\begin{abstract}
Turning is one of the initial basic machining operation that prevails in assembly and production process. Modern techniques have been practices in rapid and eco-friendly production systems. Present study deals with the investigation of turning process on EN 18 steel which is been shown its existence in automobiles industries. Turning operation was performed using a coated tool insert with varying cutting speed $(100,125$ and $150 \mathrm{~mm} / \mathrm{min})$, feed rate $(0.05,0.5,0.15 \mathrm{~mm} / \mathrm{rev})$ and depth of cut $(0.4,0.8,1.2 \mathrm{~mm})$ at both dry and MQL conditions. The results obtained was compared to optimize the effect of minimum quality lubrication on surface roughness. Experimentally it was observed that speed of $100 \mathrm{~m} / \mathrm{min}$ with combination of feed of $0.05 \mathrm{~mm} / \mathrm{rev}$ and $0.4 \mathrm{~mm}$ depth of cut was found to be optimized for surface roughness in both the cases. The mathematical model generated for surface roughness and MRR for both dry and MQL turning models having better regression fit as it closer to 100. From ANOVA analysis feed was proved to be the highest contributing factor for surface roughness and for MRR speed is the most significant factor for both dry and MQL turning
\end{abstract}

\section{Introduction}

Metal cutting is operation is the primary action that is to be performed in the modelling of components of raw material casted bulk material. In order of this modification it meets several sequences of operation as per the product that is designed for, in this criteria several researches have been practiced for the smooth and seamless operations in terms of economical, eco-friendly and accuracy. Many of the researches have been conducted in order to overcome the problems encountered during the metal cutting operation. The main problems that are registered during the cutting operation are surface roughness, cutting forces, temperature and tool life $[1,2]$. Surface roughness and cutting forces determines the outcomes of machining operation. Surface roughness is termed as one of the important terms with deals with the efficiency of machining operation and effectiveness of tool. It also deals with the economic aspects as it reduces or increases in the upcoming sequence of operations. In order to obtain good surface roughness, variation in tools and process of operation have been adopted. Tools are being coated with solid lubricant [3] with Nano size coatings over it which drastically shows its performance of decreasing the cutting forces, decrees in surface roughness and also lowers the cutting temperature. Dyi-Cheng Chen et al., clearly explained about Taguchi method for an experimental investigation with the help of various tables and diagrams [4]. Dipti Kanta Das et al. [5] used greybased Taguchi approach in investigating the surface roughness while machining EN 24 grade steel and showed that feed which one that is most dominating machining parameter for surface roughness parameters. Nilrudra Mandal et al [6] performed Second order regression analysis, Taguchi and ANOVA techniques optimization of surface roughness while machining of AISI 4340 steel. P.Jayaraman et al. [7] conducted Grey Relational Analysis with Taguchi Method for the optimization machining parameters while turning of aluminium AA 6063 T6 alloy. Minimum quantity lubrication (MQL) is one which the lubrication is done on the cutting zone with very little amount of cutting fluids. The flow rate ranges from $5 \mathrm{ml} / \mathrm{hr}$ to $500 \mathrm{ml} / \mathrm{hr}$ and the flow pressure from 2 bar to 8 bar pressure [8]. It one of the advancement the field of production engineering which has been serving in reduction of economy of production cost and lubrication disposable cost and there by serving the environment. The reason of implementation of minimum quality lubrication in daily basis of machining is due to the improper knowledge on cutting fluids disposable practices. This directly leading to effect on global and living organisms disorders. This is due to polluting of soils, rivers and other disposable areas. [9]. Although to overcome this criteria, researches have been recognised and being promoted in order of recycling/ reuse practices the cutting fluids [10]. John Arthur [11] has manually conducted the signal to noise 
ratio in their experimental research. In the previous experimental study discussed about the Turning of Inconel 625 through ANOVA of surface roughness [12]. MRR is one of the outcome considerable parameters of the machining characterizations. The more the material removal the more the work done. As material removal is one such factor which is calculated as a function of time, MRR signified to the working ability of machine, tool and production rate[13]. Acharya et al. [14] conducted turning on EN 31 at both MQL condition and wet condition and performed ANOVA on parameters like MRR and surface roughness.

The present paper deals with the experiments performed over lathe with coated tool for turning of EN 18. Taguchi analysis is applied for the surface roughness[15] and MRR to optimise the process paters in turning. Further a mathematical model has been generated based on the data obtained. In addition to that ANOVA analysis has been performed to know the most significant factor effecting the surface roughness and MRR.

\section{Experimental details}

Turning experiments were conducted on $60 \mathrm{~mm}$ length, $48 \mathrm{~mm}$ diameter and each experiment was conducted on separate workpieces and a new coated tool titanium nitride. Coated carbide insert with specifications CNMG 120408 TN2000 widia made inserts where mounted on PCLNR $2020 \mathrm{~K} 12$ Tool holder for simple turning. In order to search for the optimal process condition through a limited number of experimental runs, Taguchi's L9 orthogonal array consisting of 9 sets of data was selected. Experiments were conducted with both dry and MQL based on the process parameters, given in Table 1 . Firstly, experimental were conducted under dry condition. Than MQL lubrication was done by the oil Divyol made ST-CUT 54, the MQL was pumped by Kenco pneumatic made and hydraulic systems with fluid pressure 6 bar with a flow rate of $100 \mathrm{ml} / \mathrm{hr}$. Nozzle has been set so that the flow of MQL strikes the shearing zone of the turning operation above the insert and was at a distance of $15 \mathrm{~mm}$ as shown in Figure 1. surface roughness test with a cut-off length $0.8 \mathrm{~mm}$ was carried out at 3 different location with the aid of probe type surface roughness tester of Zeiss made surfcom flex tester and average values are reported in Table 4. Apart from surface roughness, material removal rate (MRR) was also consider in the present work. MRR has been calculated using the equation 1 by taking weight before and after machining and time taken for every experiment [17], for MQL condition workpiece are dried completely and results are recorded shown in Table 2 and 3

$$
M R R=\frac{W_{b t}-W_{a t}}{\rho \times t}
$$

$W_{b t}=$ Weight before turning $(\mathrm{gms})$

$W_{\text {at }}=$ Weight after turning (gms)

$\rho=\operatorname{density}\left(\mathrm{gms} / \mathrm{cm}^{3}\right)=8.08$ $t=$ time taken for machining $(\mathrm{sec})$

Table 1. Turning parameters and their levels

\begin{tabular}{|l|l|l|l|l|}
\hline $\begin{array}{l}\text { Machining } \\
\text { parameters }\end{array}$ & $\begin{array}{l}\text { Notation } \\
\text { (units })\end{array}$ & Level-1 & Level-2 & Level-3 \\
\hline Speed & $v(\mathrm{~m} / \mathrm{min})$ & 100 & 125 & 150 \\
\hline Feed & $f(\mathrm{~mm} / \mathrm{rev})$ & 0.05 & 0.1 & 0.15 \\
\hline Depth of cut & $d(\mathrm{~mm})$ & 0.4 & 0.8 & 1.2 \\
\hline
\end{tabular}

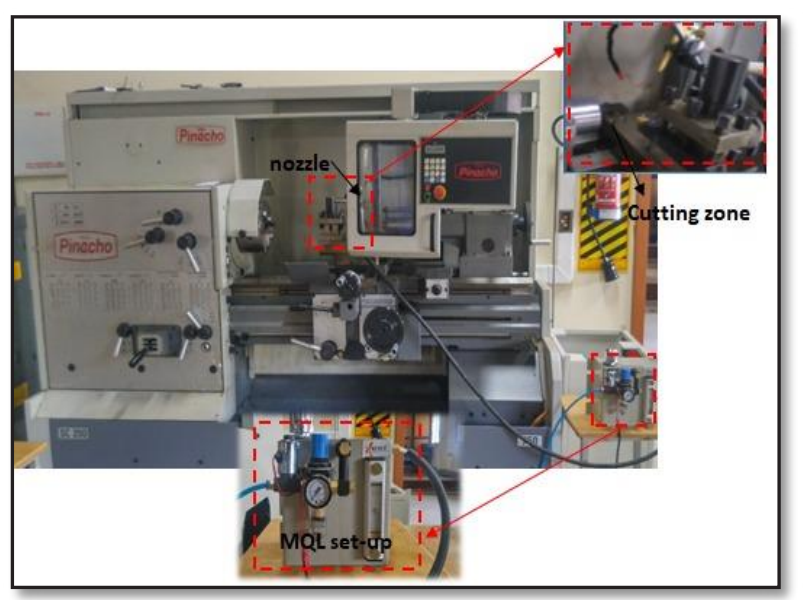

Fig. 1. Experimental Set-up

Table 2. Material Removal Rate values und dry turning

\begin{tabular}{|c|c|c|c|c|c|c|c|}
\hline \multirow[t]{2}{*}{$\begin{array}{l}\text { Sl. } \\
\text { no }\end{array}$} & \multirow[b]{2}{*}{ v } & \multirow[b]{2}{*}{ f } & \multirow[b]{2}{*}{ d } & $\begin{array}{l}\text { Weight } \\
\text { before } \\
\text { turning }\end{array}$ & $\begin{array}{l}\text { Weight } \\
\text { after } \\
\text { turning }\end{array}$ & Time & MRR \\
\hline & & & & (gms) & (gms) & $(\mathrm{sec})$ & $\begin{array}{l}\mathrm{cm}^{3} / \mathrm{mi} \\
\mathrm{n}\end{array}$ \\
\hline 1 & 1 & 1 & 1 & 850.988 & 832.044 & 12.11 & 11.616 \\
\hline 2 & 1 & 2 & 2 & 856.162 & 810.668 & 35.3 & 9.570 \\
\hline 3 & 1 & 3 & 3 & 854.318 & 840.559 & 12 & 8.514 \\
\hline 4 & 2 & 1 & 2 & 846.524 & 828.499 & 23.31 & 5.742 \\
\hline 5 & 2 & 2 & 3 & 846.555 & 824.633 & 31.22 & 5.214 \\
\hline 6 & 2 & 3 & 1 & 823.68 & 811.433 & 18.25 & 4.983 \\
\hline 7 & 3 & 1 & 3 & 852.831 & 827.225 & 87.3 & 2.178 \\
\hline 8 & 3 & 2 & 1 & 847.618 & 844.12 & 8.27 & 3.135 \\
\hline 9 & 3 & 3 & 2 & 855.201 & 846.335 & 52.5 & 1.254 \\
\hline
\end{tabular}

Table 3. Material Removal Rate values und MQL turning

\begin{tabular}{|r|r|l|l|l|l|r|r|}
\hline \multirow{2}{*}{$\begin{array}{l}\text { Sl. } \\
\text { no }\end{array}$} & \multirow{2}{*}{$\mathrm{v}$} & $\mathrm{F}$ & $\mathrm{d}$ & $\begin{array}{l}\text { Weight } \\
\text { before } \\
\text { turning }\end{array}$ & $\begin{array}{l}\text { Weight } \\
\text { after turning }\end{array}$ & Time & MQL \\
\cline { 5 - 9 } & & & & $\begin{array}{l}\text { (gms) } \\
(\mathrm{gms})\end{array}$ & \multicolumn{1}{c|}{$(\mathrm{sec})$} & $\mathrm{cm}^{3} / \mathrm{min}$ \\
\hline 2 & 1 & 2 & 2 & 839.972 & 770.37896 & 36 & 14.355 \\
\hline 3 & 1 & 3 & 3 & 834.41 & 777.46649 & 33.11 & 12.771 \\
\hline 4 & 2 & 1 & 2 & 822.927 & 806.56313 & 16.28 & 7.464 \\
\hline 5 & 2 & 2 & 3 & 825.208 & 800.36968 & 27.212 & 6.778 \\
\hline 6 & 2 & 3 & 1 & 806.346 & 795.16393 & 12.82 & 6.477 \\
\hline 7 & 3 & 1 & 3 & 836.407 & 812.80418 & 73.181 & 2.395 \\
\hline 8 & 3 & 2 & 1 & 849.912 & 845.64016 & 9.2 & 3.448 \\
\hline 9 & 3 & 3 & 2 & 847.083 & 838.85625 & 44.3 & 1.379 \\
\hline
\end{tabular}

\section{Analysis of Results}




\subsection{Analysis of $\mathrm{S} / \mathrm{N}$ ratio}

Signal to noise ratio of Taguchi analysis signal term refers to mean and noise refers to undesirable values of output characteristics. This optimizing tool is used for the measurement of quality deviation from the desired values.

The $\mathrm{S} / \mathrm{N}$ ratio performed in the present work is executed based on the smaller the better for surface roughness using the equation 1 and larger the better for MRR using equation 2. Results are reported in Table 4 and 5.

$$
\begin{aligned}
& \frac{S}{N}=-10 \log _{10}\left(\frac{1}{n} \sum_{i=1}^{n} a_{i}{ }^{2}\right) \\
& \frac{S}{N}=-10 \log _{10}\left(\frac{1}{n} \sum_{i=1}^{n} \frac{1}{b_{i}{ }^{2}}\right)
\end{aligned}
$$

Where

$\mathrm{S} / \mathrm{N}$ denotes signal to noise ratio.

$\mathrm{n}$ denotes number to tests.

$\mathrm{a}_{\mathrm{i}}$ denotes the surface roughness values.

$b_{i}$ denotes the MRR values

Table 4. L9 orthogonal array of the experimental runs and results of surface roughness

\begin{tabular}{|c|c|c|c|c|c|c|c|}
\hline \multirow{3}{*}{ exp } & \multicolumn{2}{|c|}{$\begin{array}{l}\text { Machining } \\
\text { parameters }\end{array}$} & \multicolumn{4}{c|}{ Experimental results } \\
\cline { 5 - 8 } & & & & Dry & MQL & Dry & MQL \\
\hline & $v$ & $f$ & $d$ & $(\mu \mathrm{m})$ & $\begin{array}{c}\text { Ra } \\
(\mu \mathrm{m})\end{array}$ & $\begin{array}{c}\text { MRR } \\
\left(\mathrm{m}^{3} / \mathrm{min}\right)\end{array}$ & $\begin{array}{c}\text { MRR } \\
\left(\mathrm{m}^{3} / \mathrm{min}\right)\end{array}$ \\
\hline 1 & 1 & 1 & 1 & 1.212 & 0.957 & 11.616 & 17.424 \\
\hline 2 & 1 & 2 & 2 & 2.16 & 1.706 & 9.570 & 14.355 \\
\hline 3 & 1 & 3 & 3 & 3.312 & 2.616 & 8.514 & 12.771 \\
\hline 4 & 2 & 1 & 2 & 1.44 & 1.224 & 5.742 & 7.464 \\
\hline 5 & 2 & 2 & 3 & 2.376 & 2.020 & 5.214 & 6.778 \\
\hline 6 & 2 & 3 & 1 & 3.156 & 2.683 & 4.983 & 6.477 \\
\hline 7 & 3 & 1 & 3 & 1.884 & 1.601 & 2.178 & 2.395 \\
\hline 8 & 3 & 2 & 1 & 2.412 & 2.050 & 3.135 & 3.448 \\
\hline 9 & 3 & 3 & 2 & 3.984 & 3.386 & 1.254 & 1.379 \\
\hline
\end{tabular}

\begin{tabular}{|c|c|c|c|c|c|c|c|}
\hline \multirow{3}{*}{$\exp$} & \multirow{2}{*}{\multicolumn{3}{|c|}{$\begin{array}{l}\text { Machining } \\
\text { parameters }\end{array}$}} & \multicolumn{4}{|c|}{ S/N Ratio } \\
\hline & & & & \multirow{2}{*}{$\begin{array}{c}\text { Dry } \\
\mathrm{Ra} \\
(\mu \mathrm{m})\end{array}$} & \multirow{2}{*}{$\begin{array}{c}\mathrm{MQL} \\
\mathrm{Ra}(\mu \mathrm{m})\end{array}$} & \multirow{2}{*}{$\begin{array}{c}\text { Dry } \\
\text { MRR } \\
(\mathrm{m} 3 / \mathrm{min})\end{array}$} & \multirow{2}{*}{$\begin{array}{c}\text { MQL } \\
\text { MRR } \\
(\mathrm{m} 3 / \mathrm{min})\end{array}$} \\
\hline & $\mathrm{V}$ & $\mathrm{F}$ & $\mathrm{d}$ & & & & \\
\hline 1 & 1 & 1 & 1 & -1.6701 & 0.3818 & 21.301 & 24.822 \\
\hline 2 & 1 & 2 & 2 & -6.6891 & -4.6396 & 19.618 & 23.140 \\
\hline 3 & 1 & 3 & 3 & -10.4018 & -8.3528 & 18.602 & 22.12 \\
\hline 4 & 2 & 1 & 2 & -3.1672 & -1.7556 & 15.181 & 17.459 \\
\hline 5 & 2 & 2 & 3 & -7.5169 & -6.1070 & 14.343 & 16.622 \\
\hline 6 & 2 & 3 & 1 & -9.9827 & -8.5724 & 13.949 & 16.227 \\
\hline 7 & 3 & 1 & 3 & -5.5016 & -4.0878 & 6.761 & 7.586 \\
\hline 8 & 3 & 2 & 1 & -7.6475 & -6.2351 & 9.9247 & 10.751 \\
\hline 9 & 3 & 3 & 2 & -12.0064 & -10.5937 & 1.9659 & 2.7912 \\
\hline
\end{tabular}

Table 5. signal to noise ratio for roughness and MRR

The average values of each parameter for each level has been calculated and reported in Table 6 and Table 7 in both the cases ie., dry and MQL turning for Surface roughness and MRR. It was observed that from table 6 and 7 that for Surface roughness and MRR, dry and MQL turning the optimum condition for turning EN18 that cutting speed at level $1(100 \mathrm{~m} / \mathrm{min})$, feed at level $1(0.05$ $\mathrm{mm} / \mathrm{rev})$ and depth of cut at level $1(0.4 \mathrm{~mm})$. From the table 6 it is also clear that rank 1 indicates that feed is the most contributing parameter in both the cases when turning E18 and from table 7, rank 1 is against cutting velocity which indicated cutting velocity is most significant parameter for MRR.

Table 6. $\mathrm{S} / \mathrm{N}$ Response table for surface roughness

\begin{tabular}{|l|c|c|c|c|c|c|}
\hline & \multicolumn{3}{|c|}{ Dry Turning (Ra) } & \multicolumn{3}{c|}{ MQL Turning (Ra) } \\
\hline Level & $v$ & $F$ & $d$ & $V$ & $f$ & $D$ \\
\hline 1 & $\mathbf{- 6 . 2 5 4}$ & $\mathbf{- 3 . 4 4 6}$ & $\mathbf{- 6 . 4 3 3}$ & $\mathbf{- 4 . 2 0 6}$ & $\mathbf{- 1 . 8 2 3}$ & $\mathbf{- 4 . 8 1 0}$ \\
\hline 2 & -6.889 & -7.285 & -7.288 & -5.477 & -5.661 & -5.664 \\
\hline 3 & -8.385 & -10.797 & -7.807 & -6.974 & -9.173 & -6.183 \\
\hline Delta & 2.132 & 7.351 & 1.373 & 2.767 & 7.351 & 1.373 \\
\hline Rank & 2 & 1 & 3 & 2 & 1 & 3 \\
\hline
\end{tabular}

Table 7. S/N Response table for MRR

\begin{tabular}{|l|c|c|c|c|c|c|}
\hline & \multicolumn{3}{|c|}{ Dry Turning (MRR) } & \multicolumn{3}{c|}{ MQL Turning (MRR) } \\
\hline Level & $v$ & $f$ & $D$ & $v$ & $f$ & $d$ \\
\hline 1 & $\mathbf{1 9 . 8 4 1}$ & $\mathbf{1 4 . 6 2 9}$ & $\mathbf{1 5 . 0 5 9}$ & $\mathbf{2 3 . 3 6 3}$ & $\mathbf{1 6 . 8 3 8}$ & $\mathbf{1 7 . 2 6 8}$ \\
\hline 2 & 14.492 & 11.506 & 12.255 & 16.770 & 13.716 & 14.465 \\
\hline 3 & 6.217 & 14.415 & 13.236 & 7.045 & 16.624 & 15.445 \\
\hline Delta & 13.623 & 3.123 & 2.803 & 16.317 & 3.123 & 2.803 \\
\hline Rank & 1 & 2 & 3 & 1 & 2 & 3 \\
\hline
\end{tabular}

\subsection{Development of mathematical model with regression analysis}

Utilizing the outcomes from experimental values, mathematical regression model has been developed with backword elimination method and alpha to remove 0.5 in MINITAB 18 software. The regression model for roughness and MRR for dry and MQL turning reported as equation 3 , equation 4 , equation 5 and equation 6 . For all the cases the R-Sq and R-Sq(ad) are reported. R-sq is the goodness response of regression model generally lie in between $0 \%$ to $100 \% .0 \%$ represents a model that does not explain any of the variation in the response variable around its mean and $100 \%$ represents a model that explains all of the variation in the response variable around its mean. Usually, the larger the R-sq, the better the regression model fits. In the present for all cases the regression models are closer to $100 \%$ therefore one can tell that these models having better regression fit.

Dry $\mathrm{Ra}=0.893-0.057$ speed +0.697 feed

- 0.684 depth of cut +0.211 speed*depth of cut

+0.197 feed*depth of cut

$R-s q=98.93 \% R-s q(\operatorname{adj})=97.16 \%$

MQL Ra $=0.649-0.026$ speed +0.623 feed

-0.592 depth of cut

+0.1957 speed*depth of cut 0.1458 feed*depth of cut

$R-s q=99.24 \% R-s q(\operatorname{adj})=97.96 \%$

Dry MRR $=28.85-0.1228$ speed

+856 feed- 27.4 depth of cut -11.12 speed*feed

+0.145 speed*depth of cut

+653 feed*depth of cut

$\mathrm{R}-\mathrm{sq}=98.27 \%$ R-sq(adj) $=93.07 \%$

MQL MRR $=47.8-0.2076$ speed +1521 feed -51.0 depth of cut -20.0 speed $^{*}$ feed 
+0.279 speed $*$ depth of cut

+1182 feed*depth of cut

R-sq $=98.50 \%$ R-sq(adj $)=94.01 \%$

\subsection{Analysis of Variance}

Analysis of variance (ANOVA) was initiated by Sir Ronald Fisher [16]. This analysis in present paper has been carried out for significance level of $5 \%$, at $95 \%$ confidence level. The purpose of ANOVA is to investigate the machining parameter that significantly affects the response variables [17]. In the present paper ANOVA was performed for all the cases and shown in Table 8, Table 9, Table 10 and Table 11. From ANOVA analysis as shown in Table 8 and 9 it is clear that feed is most significant parameter in both case of turning that is for dry turning i.e., feed contribution is about $48.55 \%$ and for MQL turning $51.57 \%$.

Table 8. ANOVA for Ra at DRY Turning condition.

\begin{tabular}{|l|c|c|c|c|c|c|}
\hline Source & DF & Adj SS & $\begin{array}{c}\text { Adj } \\
\text { MS }\end{array}$ & F-Value & P-Value & \%Cont \\
\hline Regression & 5 & 6.487 & 1.297 & 55.70 & 0.004 & \\
\hline Speed & 1 & 0.001 & 0.001 & 0.08 & 0.799 & 0.18 \\
\hline Feed & 1 & 0.268 & 0.268 & 11.53 & 0.043 & 48.55 \\
\hline Depth of cut & 1 & 0.085 & 0.085 & 3.65 & 0.152 & 15.39 \\
\hline $\begin{array}{l}\text { Speed*depth of } \\
\text { cut }\end{array}$ & 1 & 0.093 & 0.093 & 4.01 & 0.139 & 16.84 \\
\hline $\begin{array}{l}\text { feed*depth of } \\
\text { cut }\end{array}$ & 1 & 0.082 & 0.082 & 3.50 & 0.158 & 14.85 \\
\hline Error & 3 & 0.069 & 0.023 & & & 4.16 \\
\hline Total & 8 & 6.557 & & & & 100 \\
\hline
\end{tabular}

Table 9. ANOVA for Ra at MQL Turning condition.

\begin{tabular}{|l|c|c|c|c|c|c|}
\hline Source & DF & Adj SS & $\begin{array}{c}\text { Adj } \\
\text { MS }\end{array}$ & F-Value & P-Value & \%Cont \\
\hline Regression & 5 & 4.662 & 0.932 & 77.88 & 0.002 & \\
\hline Speed & 1 & 0.001 & 0.001 & 0.03 & 0.873 & 0.24 \\
\hline Feed & 1 & 0.214 & 0.214 & 17.93 & 0.024 & 51.57 \\
\hline Depth of cut & 1 & 0.063 & 0.063 & 5.32 & 0.104 & 15.18 \\
\hline $\begin{array}{l}\text { Speed*depth of } \\
\text { cut }\end{array}$ & 1 & 0.080 & 0.080 & 6.72 & 0.081 & 19.28 \\
\hline $\begin{array}{l}\text { feed*depth of } \\
\text { cut }\end{array}$ & 1 & 0.045 & 0.045 & 3.73 & 0.149 & 10.84 \\
\hline Error & 3 & 0.036 & 0.012 & & & 2.89 \\
\hline Total & 8 & 4.698 & & & & 100 \\
\hline
\end{tabular}

Table 10. ANOVA for MRR at DRY Turning condition.

\begin{tabular}{|l|c|c|c|c|c|c|}
\hline Source & DF & $\begin{array}{c}\text { Adj } \\
\text { SS }\end{array}$ & Adj MS & F-Value & P-Value & \%Cont \\
\hline Regression & 6 & 95.625 & 15.9376 & 18.97 & 0.051 & \\
\hline Speed & 1 & 3.388 & 3.3878 & 4.03 & 0.182 & 25.32 \\
\hline Feed & 1 & 2.186 & 2.1861 & 2.60 & 0.248 & 16.34 \\
\hline Depth of cut & 1 & 1.796 & 1.7958 & 2.14 & 0.281 & 13.42 \\
\hline Speed*Feed & 1 & 1.970 & 1.9703 & 2.34 & 0.265 & 14.73 \\
\hline $\begin{array}{l}\text { Speed*depth of } \\
\text { cut }\end{array}$ & 1 & 1.462 & 1.4619 & 1.74 & 0.318 & 10.93 \\
\hline $\begin{array}{l}\text { feed*depth of } \\
\text { cut }\end{array}$ & 1 & 1.736 & 1.7356 & 2.07 & 0.287 & 12.97 \\
\hline Error & 2 & 1.681 & 0.8403 & & & 6.28 \\
\hline Total & 8 & 97.306 & & & & 100 \\
\hline
\end{tabular}

Table 11. ANOVA for MRR at MQL Turning condition.

\begin{tabular}{|l|c|c|c|c|c|c|}
\hline Source & DF & Adj SS & $\begin{array}{c}\text { Adj } \\
\text { MS }\end{array}$ & $\begin{array}{c}\text { F- } \\
\text { Value }\end{array}$ & $\begin{array}{c}\text { P- } \\
\text { Value }\end{array}$ & \%Cont \\
\hline Regression & 6 & 248.211 & 41.368 & 21.92 & 0.044 & \\
\hline Speed & 1 & 9.681 & 9.681 & 5.13 & 0.152 & 22.96 \\
\hline Feed & 1 & 6.913 & 6.913 & 3.66 & 0.196 & 16.39 \\
\hline Depth of cut & 1 & 6.231 & 6.231 & 3.30 & 0.211 & 14.78 \\
\hline Speed*Feed & 1 & 6.382 & 6.382 & 3.38 & 0.207 & 15.14 \\
\hline $\begin{array}{l}\text { Speed*depth of } \\
\text { cut }\end{array}$ & 1 & 5.383 & 5.383 & 2.85 & 0.233 & 12.77 \\
\hline $\begin{array}{l}\text { feed*depth of } \\
\text { cut }\end{array}$ & 1 & 5.690 & 5.690 & 3.02 & 0.225 & 13.49 \\
\hline Error & 2 & 3.774 & 1.887 & & & 4.48 \\
\hline Total & 8 & 251.985 & & & & 100 \\
\hline
\end{tabular}

From ANOVA analysis from Table 10 and 11 it is clear that speed is most significant parameter in both case of turning that is for dry turning i.e., speed contribution is about $48.55 \%$ and for MQL turning $51.57 \%$.

\section{Conclusion}

Present paper deals with the optimization of cutting forces and surface roughness values evolved during machining EN18 steel under dry and MQL conditions. As stated, the methodology of Taguchi design provides the efficient optimum conditions for machining parameters. The following are the conclusions detailed from the work.

1. The optimum conditions for surface roughness and MRR for both dry and MQL turning was cutting speed at level $1(100 \mathrm{~m} / \mathrm{min})$, feed at level $1(0.05 \mathrm{~mm} / \mathrm{rev})$ and depth of cut at level $1(0.4 \mathrm{~mm})$.

2. The mathematical model generated for surface roughness and MRR for both dry and MQL turning models having better regression fit as it closer to 100 .

3. ANOVA analysis feed found to be the most contributing factor for surface roughness values in both dry and MQL conditions with $48.55 \%$ and $51.57 \%$.

4. ANOVA analysis speed found to be the most contributing factor for MRR in both dry and MQL conditions with $25.32 \%$ and $22.96 \%$ respectively.

\section{REFERENCES}

1. Altin, A., Nalbant, M., \& Taskesen, A. Mater Design, 28(9), 2518-2522 (2007).

2. Aslantas, K., Ucun, I., \& Cicek, A. Wear, 274, 442-451 (2012).

3. Kiliçay, K., \& Ulutan, M. Int. J. Precis. Eng. Manuf., 17(4), 517-524 (2016)

4. Chen, D. C., \& Huang, J. Y. Mater. Sci. Eng. A, 464(1-2), 135-140 (2007) 
5. Das, D. K., Sahoo, A. K., Das, R., \& Routara, B. C. (2014). Procedia Mater. Sci, 6, 1351-1358 (2014)

6. Mandal, N., Doloi, B., \& Mondal, B. Int J Refract Met H, 38, 40-46 (2013).

7. P. Jayaraman, "Procedia Eng, 97, 197-204 (2014).

8. Obikawa, T., Kamata, Y., \& Shinozuka, J. Int. J. Mach. 46(14), 1854-1861 (2006)

9. Yoo, S., Kim, D. Int. J. Precis. Eng. Manuf. 14, 875-880 (2013)

10. Berger, Mitchell H., et al, U.S. Patent No. 5,983,910. 16 Nov. (1999).

11. Betts, John Arthur. Signal processing, modulation and noise. English universities Press, 1970.

12. Kosaraju, Satyanarayana, M. Vijay Kumar, and N. Sateesh. Material Today 5,2 5343-5348. (2018)Hassan, K., Kumar, A., \& Garg, M. P, Int J Eng Res Appl, 2(2), 1581-1590,(2012).

13. Acharya, S. S., \& Karwande, R. L. Int. J. Eng. Res, 6(2), (2015).

14. Suresh Kumar Tummala, Dhasharatha G, E3S Web of Conferences 87, 01030 (2019)

15. Satyanarayana, Kosaraju, Anne Venu Gopal, and Popuri Bangaru Babu., IJMMM. 13(2-3), 191-202. (2013)

16. Yogeswara Reddy B, Srinivas Rao J, Suresh Kumar T, Nagarjuna A, Int J of Inn Tech and Exp Engg, 8(11), 2019

17. Das, S. R., Dhupal, D., \& Kumar, A. J Mech Sci Technol 29(10), 4329-4340, (2015). 